\title{
Problems and Constraints in Banana Cultivation: A Case Study in Bhagalpur District of Bihar, India
}

\author{
Priyanka Kumari $^{1^{*}}$, K.M. Singh ${ }^{1}$ and Santosh Kumar Atre ${ }^{2}$ \\ ${ }^{1}$ Department of Agricultural Economics, Dr. Rajendra Prasad Central Agricultural \\ University, Pusa-848125, India \\ ${ }^{2}$ Horticulture Society of India, New Delhi \\ *Corresponding author
}

\section{A B S T R A C T}

India has been predominantly agrarian economy since time immemorial. Development efforts over the last four decades have doubtless strengthened our industrial base. The

Keywords

Banana, Pre-harvest contractors, Ready marke, Regular income, Constraints

Article Info

Accepted:

15 June 2018

Available Online:

10 July 2018 banana in the state has been reportedly being cultivated under traditional manner. By and large, the farmers are cultivating only the traditional varieties of banana. Perishability is one of the important constraints in banana production and marketing. Processing opportunities are absent to a great extent. The price behaviour in banana crop has been violently fluctuating and the farmers are put to great loss and the consumer is also not benefited. The non-availability of credit was important to the extent of 88.0, 77.0 and 33.0 per cent for semi-medium, marginal \&small and medium and large category of banana growers, respectively. The non-availability of proper market and dominance of pre-harvest contractors was considered the limiting factor in the order of 100, 64 and 44 per cent by three categories of growers, respectively with overall mean average as 77 per cent. All sample growers were of the opinion that the soil of the area is suitable for banana cultivation as well as its profitable nature. As far as its 'ready market' aspect was concerned 21, 24 and 8 growers favoured it, while 'regular income' aspect was favoured by 21,25 and 7 growers respectively.

\section{Introduction}

In Banana production India has first rank in the world. In agriculture, the production of fruits and vegetables are of so vital importance that it provide three to four time more income than cereals per unit of land. The fruit crops hold a great promise for accelerating income of the farmers. Realizing the importance of fruit cultivation many farmers are diverting their resources towards plantation of fruit crops. Area under fruit crops is, therefore, increasing day by day (Maurya et al., 1996). Banana could be considered as poor man's apple and it is available throughout the year unlike seasonal availability of other fruits.

Bihar state rank in banana production in India is seven where area is 34.31 thousand hectare and production is 1435.78 thousand M.T. the banana in the state has been reportedly being cultivated under traditional manner (NHB, 
2013-14). By and large, the farmers are cultivating only the traditional varieties of banana. The profitability of the banana products has not been quite substantial. In addition to several problems in production of banana, some other problem posses a severe threat to banana producers. These are regional variations in costs, returns and resource use efficiency. Further, within the regions there is variation among different farm size groups.

Perishability is one of the important constraints in banana production and marketing. Processing opportunities are absent to a great extent. Therefore the value addition is not achieved and further the quality of banana deteriorates so fast and hence remunerative prices for banana are not obtained. The price behaviour in banana crop has been violently fluctuating and the farmers are put to great loss and the consumer is also not benefited. The major share of the consumer's price is reportedly taken away by middleman and other intermediaries. Cooperative efforts are lacking in marketing and processing. A thorough review of status of banana production, marketing and exports has revealed that there exist several gaps in the knowledge and information on all the above issue.

The profitability of banana production depends upon the income generating capacity and cost structure of the enterprises. However, much information is not available on the economic aspect of banana cultivation at micro level. So far no systematic studies have been conducted on the economics of production and marketing of banana in Bihar (Bhagalpur). Hence a study encompassing the above-mentioned issues is a felt need and it is quite justified in taking up such a study. In order to find the solution to some of the problems discussed above, the present study has been contemplated in Bhagalpur.

\section{Materials and Methods}

Selection of 60 respondents in Bhagalpur district, Naugachhia block and three villages Pakara, Jamunia, and Tetari randomly selected on the basis of highest quantity of banana production in the region of Bihar state. Bhagalpur district has been selected on the basis of the highest quantity of banana production in the region.

One block namely Naugachhia of Bhagalpur district having a maximum area under Banana cultivation has been selected. From selected block, a cluster of 3 villages has been selected randomly. And from each of selected village, sample of 20 banana growers have been selected randomly. Selection based on multistage-technique and pre-tested schedules / primary data.

The data about the Agro-Biological factors, economic factors, marketing factors, suitability of soil, profitability, ready market, regular market, income from by-product were collected from the sample growers. The information regarding the state, districts, blocks and villages were obtained from the published data of the Directorate Economics and Statistics, National Horticultural Board, District Horticultural Office and Block Office.

\section{Results and Discussion}

Whereas the problems and constraints affecting production and marketing of banana viz. agro-biological and economics faced by the banana growers.

Classification of sample banana grower is presented in table 1 . It reveals that the sample (60) includes 26 (43.33 per cent) of the marginal and small category of farmers, while semi- medium and medium and large category includes 25 (41.67 per cent) and 9 (15.00 percent) respectively. 
Composition of farm family and education level of sample banana farmers

The composition of the farm family and the education level of the family head have been presented in Table 2 and Table 3, respectively. It is found that the average size of the family of three categories of farm families was 9,9 and 12 respectively. In terms of the sex-wise composition of the family, it includes 3 male members, while female and children member included 3 and 4 on an overall basis with a total number of members as 10 .

The education level of head of household is presented in Table 3. The illiteracy (11.54 per cent) was found in marginal and small category growers only. Illiteracy percentage in semi-medium and medium and large was zero. Among marginal and small category of banana grower highest percentage (19.23) in primary education. In terms of graduate and above level of education, medium size growers had highest (33.33 per cent) proportion while the semi-medium farmers with 24.0 per cent. The higher secondary level was highest (36.0 per cent) under semi-medium category while high school (38.46 per cent) on marginal and small category.

\section{Average size of land holding and area under banana}

The size of land holding of sample banana farms is presented in Table 4. The operational land holding size ranged between 1.52, 3.14, and 8.55 ha among three categories of farms with overall mean as 3.16 ha. The table reveals that a few marginal and small farmers took land on lease, while semi-medium and medium and large farmers found leasing out their land, with mean value as 0.03 and 0.04 ha, respectively.

The percentage area under banana cultivation and variety/cultivar wise area has been presented in table 5.1.3. The table reveals that marginal and small farmers devoted maximum, (76.64 per cent) area under the banana, while semi-medium and medium and large category growers devoted 56.49 and 42.28 per cent area, respectively, while the reverse order was found with respect to the allocation of the area under other crops (table 4). This indicates that because of cash needs and labour intensive nature of crop (banana) marginal and small farmers allotted more area under this crop.

\section{Constraints in production and marketing of banana}

To study this aspect the sample banana growers/farmers were asked for their opinion over structured questions during the survey and category-wise results are presented and discussed in the following sub-sections.

\section{Constraints affecting banana production}

The constraints affecting banana production was studied on the basis of growers response on structured questions, based on their experience about banana production. These broadly classified into agro-biological, economic and marketing factors. The result has presented in table 5. The agro-biological constraints included variety/cultivar, the severity of pest and diseases, while the economic factors include scarcity of labourer, higher wages, the cost of inputs and credit availability. The scarcity of labour was considered as the most important limiting factor ( 88.89 per cent) by medium category growers, while it was least important (19.23 per cent) for the marginal and small category. The high cost of inputs was considered important by all three categories of growers. The non-availability of credit was important to the extent of 88.0, 77.0 and 33.0 per cent for semi-medium, marginal \&small and medium and large category of banana growers, respectively. 
The marketing factors included nonavailability of proper market and dominance of pre-harvest contractors, price fluctuation and no practice of grading. All three categories of growers considered these factors affecting banana production. The price fluctuation was considered by all sample growers. The non-availability of proper market and dominance of pre-harvest contractors was considered the limiting factor in the order of 100, 64 and 44 per cent by three categories of growers, respectively with overall mean average as 77 per cent.

Table 6 shows that all sample growers were of the opinion that the soil of the area is suitable for banana cultivation as well as its profitable nature. As far as its 'ready market' aspect was concerned 21, 24 and 8 growers favoured it, while 'regular income' aspect was favoured by 21,25 and 7 growers respectively.

The income from by-products was considered favourable by all marginal and small category growers only (table 5.9). This may be due to dependence on hired labourer by other two category growers which are obvious.

\section{Production constraints}

The scarcity of labour was considered as the most important limiting factor ( 88.89 per cent) by medium and large category growers, while it was least important (19.23 per cent) for marginal and small category.

High cost of inputs was considered important by all three categories of growers.

The non-availability of credit was important to the extent of 88.0 per cent for semi-medium and 77.0 per cent by marginal and small growers.

No institutional credit was available to them. Frequent cyclone and heavy rainfall were the major natural calamity due to which their crop was damaged, resulting heavy economic loss. There was no provision of crop insurance also.

\section{Marketing constraints}

All three categories of growers considered marketing factors, viz. non-availability of proper market, and dominance of pre-harvest contractors, price-fluctuation and no practice of grading affecting banana production.

The price fluctuation was considered by all sample growers.

The non-availability of proper market and dominance of pre-harvest contractors was considered the limiting factor in order of 100 , 64 and 44 per cent by three categories of growers, respectively.

Most of the quantity of produce is marketed through pre-harvest contractors, which were reported to be their financer. Marketing linkages have not yet developed and stabilized due to large number of small un-organized banana producers.

They sell the produce under Pre-harvest contractors to trader.

The growers should be trained on its nutrient and water management as well as on postharvest management technology. This will help in enhancing resource use efficiency, reducing cost of production and enhancing profitability.

The growers are required to be trained in management of ratoon crops for enhanced production/profitability.

There is need of organizing growers to form Producer Company on the lines of Mahgrapes, Mahamango, Mahabanana etc. prevailing in Maharashtra state. 
Table.1 Classification of sample banana farmers

\begin{tabular}{|c|c|c|c|}
\hline \multirow{2}{*}{$\begin{array}{l}\text { Category of banana } \\
\text { growers }\end{array}$} & \multirow{2}{*}{$\begin{array}{l}\text { Operational } \\
\text { holding (ha) }\end{array}$} & \multicolumn{2}{|c|}{ Study Sample } \\
\hline & & No. & Percentage \\
\hline Marginal and Small & $<2.0$ ha & 26 & 43.33 \\
\hline Semi-Medium & $2.0-4.0$ ha & 25 & 41.67 \\
\hline Medium and Large & $>4.0$ ha & 09 & 15.00 \\
\hline \multicolumn{2}{|c|}{ Total } & 60 & 100.00 \\
\hline
\end{tabular}

Table.2 Average family size of the sample households

\begin{tabular}{|c|c|c|c|c|}
\hline Category of banana grower & Male & Female & Children & Overall \\
\hline $\begin{array}{l}\text { Marginal and Small } \\
\left(\mathbf{n}_{1}=26\right)\end{array}$ & $\begin{array}{c}3 \\
(33.33)\end{array}$ & $\begin{array}{c}2 \\
(22.22)\end{array}$ & $\begin{array}{c}4 \\
(44.45)\end{array}$ & $\begin{array}{c}9 \\
(100.00)\end{array}$ \\
\hline $\begin{array}{l}\text { Semi-Medium } \\
\left(\mathbf{n}_{2}=\mathbf{2 5}\right)\end{array}$ & $\begin{array}{c}3 \\
(33.33)\end{array}$ & $\begin{array}{c}3 \\
(33.33)\end{array}$ & $\begin{array}{c}3 \\
(33.33)\end{array}$ & $\begin{array}{c}9 \\
(100.00)\end{array}$ \\
\hline $\begin{array}{l}\text { Medium \&Large } \\
\left(n_{3}=9\right)\end{array}$ & $\begin{array}{c}4 \\
(33.33)\end{array}$ & $\begin{array}{c}4 \\
(33.33)\end{array}$ & $\begin{array}{c}4 \\
(33.33)\end{array}$ & $\begin{array}{c}12 \\
(100.00)\end{array}$ \\
\hline $\begin{array}{c}\text { Total } \\
(\mathrm{n}=60)\end{array}$ & $\begin{array}{c}3 \\
(\mathbf{3 0 . 0 0})\end{array}$ & $\begin{array}{c}3 \\
(30.00)\end{array}$ & $\begin{array}{c}4 \\
(40.00)\end{array}$ & $\begin{array}{c}10 \\
(100.00)\end{array}$ \\
\hline
\end{tabular}

Note: Figures in parenthesis indicates percentage to the total.

Table.3 Educational level of head of the household

\begin{tabular}{|c|c|c|c|c|c|c|}
\hline \multirow{2}{*}{$\begin{array}{l}\text { Category } \\
\text { of banana } \\
\text { grower }\end{array}$} & \multicolumn{6}{|c|}{ Education Level } \\
\hline & Illiterate & Primary & $\begin{array}{l}\text { High } \\
\text { School }\end{array}$ & $\begin{array}{l}\text { Higher } \\
\text { Secondary }\end{array}$ & & Total \\
\hline $\begin{array}{l}\text { Marginal and } \\
\text { Small }\left(n_{1}=26\right)\end{array}$ & $\begin{array}{c}3 \\
(11.54)\end{array}$ & $\begin{array}{c}5 \\
(19.23)\end{array}$ & $\begin{array}{c}10 \\
(38.46)\end{array}$ & $\begin{array}{c}3 \\
(11.54)\end{array}$ & $\begin{array}{c}5 \\
(19.23)\end{array}$ & $\begin{array}{c}26 \\
(100.00)\end{array}$ \\
\hline $\begin{array}{l}\text { Semi-medium } \\
\left(\mathbf{n}_{2}=25\right)\end{array}$ & $\begin{array}{c}0 \\
(0.00)\end{array}$ & $\begin{array}{c}2 \\
(8.00)\end{array}$ & $\begin{array}{c}8 \\
(32.00)\end{array}$ & $\begin{array}{c}9 \\
(36.00)\end{array}$ & $\begin{array}{c}6 \\
(24.00)\end{array}$ & $\begin{array}{c}25 \\
(100.00)\end{array}$ \\
\hline $\begin{array}{l}\operatorname{Medium} \text { and } \\
\operatorname{Large}\left(n_{3}=9\right)\end{array}$ & $\begin{array}{c}0 \\
(0.00)\end{array}$ & $\begin{array}{c}1 \\
(11.11)\end{array}$ & $\begin{array}{c}3 \\
(33.33)\end{array}$ & $\begin{array}{c}2 \\
(22.23)\end{array}$ & $\begin{array}{c}3 \\
(33.33)\end{array}$ & $\begin{array}{c}9 \\
(100.00)\end{array}$ \\
\hline Total $(n=60)$ & $\begin{array}{c}3 \\
(5.00)\end{array}$ & $\begin{array}{c}8 \\
(13.33)\end{array}$ & $\begin{array}{c}21 \\
(35.00)\end{array}$ & $\begin{array}{c}14 \\
(23.33)\end{array}$ & $\begin{array}{c}14 \\
(23.33)\end{array}$ & $\begin{array}{c}60 \\
(100.00)\end{array}$ \\
\hline
\end{tabular}

Note: Figures in parenthesis shows percent value 
Table.4 Average size of land holding (ha)

\begin{tabular}{|c|c|c|c|c|c|c|}
\hline $\begin{array}{l}\text { Category of banana } \\
\text { farmers }\end{array}$ & $\begin{array}{l}\text { Owned } \\
\text { land }\end{array}$ & $\begin{array}{l}\text { Leased-in } \\
\text { Land }\end{array}$ & $\begin{array}{l}\text { Leased- } \\
\text { out Land }\end{array}$ & $\begin{array}{l}\text { Operational } \\
\text { holding }\end{array}$ & $\begin{array}{c}\text { Area } \\
\text { under } \\
\text { banana }\end{array}$ & $\begin{array}{l}\text { Area under } \\
\text { another crop }\end{array}$ \\
\hline $\begin{array}{l}\text { Marginal and small } \\
\left(n_{1}=26\right)\end{array}$ & 1.47 & 0.07 & 0.02 & $\begin{array}{c}1.52 \\
(100.00)\end{array}$ & $\begin{array}{c}1.17 \\
(76.64)\end{array}$ & $\begin{array}{c}0.35 \\
(23.36)\end{array}$ \\
\hline $\begin{array}{l}\text { Semi-medium } \\
\left(\mathbf{n}_{2}=\mathbf{2 5}\right)\end{array}$ & 3.22 & 0.00 & 0.08 & $\begin{array}{c}3.14 \\
(100.00)\end{array}$ & $\begin{array}{c}1.78 \\
(56.49)\end{array}$ & $\begin{array}{c}1.36 \\
(43.51)\end{array}$ \\
\hline $\begin{array}{l}\text { Medium and large } \\
\left(n_{3}=9\right)\end{array}$ & 8.55 & 0.00 & 0.00 & $\begin{array}{c}8.55 \\
(100.00)\end{array}$ & $\begin{array}{c}3.70 \\
(42.28)\end{array}$ & $\begin{array}{c}4.85 \\
(56.72)\end{array}$ \\
\hline $\begin{array}{l}\text { Total } \\
(\mathrm{n}=60)\end{array}$ & 3.17 & 0.03 & 0.04 & $\begin{array}{c}3.16 \\
(100.00)\end{array}$ & $\begin{array}{c}1.77 \\
(\mathbf{5 5 . 9 5})\end{array}$ & $\begin{array}{c}1.39 \\
(44.05)\end{array}$ \\
\hline
\end{tabular}

Note: Figures in parenthesis indicates percentage area under banana to operational holding.

Table.5 Factors affecting banana production based on farmers opinion

\begin{tabular}{|c|c|c|c|c|}
\hline \multirow[t]{2}{*}{ Constraints } & \multicolumn{4}{|c|}{ Category of banana grower } \\
\hline & $\begin{array}{c}\text { Marginal } \\
\text { and Small } \\
\left(\mathbf{n}_{1}=\mathbf{2 6}\right)\end{array}$ & $\begin{array}{l}\text { Semi- } \\
\text { Medium } \\
\left(\mathbf{n}_{2}=25\right)\end{array}$ & $\begin{array}{c}\text { Medium } \\
\text { \&Large } \\
\left(\mathbf{n}_{3}=9\right)\end{array}$ & $\begin{array}{c}\text { Overall } \\
(n=60)\end{array}$ \\
\hline \multicolumn{5}{|l|}{ 1. Agro-Biological factors } \\
\hline $\begin{array}{l}\text { Lack of Suitable Variety/ } \\
\text { cultivar }\end{array}$ & $\begin{array}{c}26 \\
(100.00)\end{array}$ & $\begin{array}{c}25 \\
(100.00)\end{array}$ & $\begin{array}{c}9 \\
(100.00)\end{array}$ & $\begin{array}{c}60 \\
(100.00)\end{array}$ \\
\hline $\begin{array}{l}\text { Severity of pests and } \\
\text { diseases }\end{array}$ & $\begin{array}{c}26 \\
(100.00)\end{array}$ & $\begin{array}{c}25 \\
(100.00)\end{array}$ & $\begin{array}{c}9 \\
(100.00)\end{array}$ & $\begin{array}{c}60 \\
(100.00)\end{array}$ \\
\hline \multicolumn{5}{|l|}{ 2. Economic factors } \\
\hline Scarcity of labour & $\begin{array}{c}5 \\
(19.23)\end{array}$ & $\begin{array}{c}15 \\
(60.00)\end{array}$ & $\begin{array}{c}8 \\
(88.89)\end{array}$ & $\begin{array}{c}28 \\
(46.67)\end{array}$ \\
\hline High labour wages & $\begin{array}{c}26 \\
(100.00)\end{array}$ & $\begin{array}{c}25 \\
(100.00)\end{array}$ & $\begin{array}{c}9 \\
(100.00)\end{array}$ & $\begin{array}{c}60 \\
(100.00)\end{array}$ \\
\hline High cost of inputs & $\begin{array}{c}26 \\
(100.00)\end{array}$ & $\begin{array}{c}25 \\
(100.00)\end{array}$ & $\begin{array}{c}9 \\
(100.00)\end{array}$ & $\begin{array}{c}60 \\
(100.00)\end{array}$ \\
\hline $\begin{array}{l}\text { Non-availability of } \\
\text { institutional credit facility }\end{array}$ & $\begin{array}{c}20 \\
(76.92)\end{array}$ & $\begin{array}{c}22 \\
(88.00)\end{array}$ & $\begin{array}{c}3 \\
(33.33)\end{array}$ & $\begin{array}{c}45 \\
(75.00)\end{array}$ \\
\hline \multicolumn{5}{|l|}{ 3. Marketing factors } \\
\hline $\begin{array}{l}\text { Non-availability of proper } \\
\text { market and Dominance of } \\
\text { pre-harvest Contractors }\end{array}$ & $\begin{array}{c}26 \\
(100.00)\end{array}$ & $\begin{array}{c}16 \\
(64.00)\end{array}$ & $\begin{array}{c}4 \\
(44.44)\end{array}$ & $\begin{array}{c}46 \\
(76.67)\end{array}$ \\
\hline Price fluctuation & $\begin{array}{c}26 \\
(100.00)\end{array}$ & $\begin{array}{c}25 \\
(100.00)\end{array}$ & $\begin{array}{c}9 \\
(100.00)\end{array}$ & $\begin{array}{c}60 \\
(100.00)\end{array}$ \\
\hline
\end{tabular}

Note: Figure in brackets shows per cent. 
Table.6 Suitability aspect of banana cultivation (no. of grower)

\begin{tabular}{|c|c|c|c|c|c|}
\hline Category of banana grower & $\begin{array}{l}\text { Suitability } \\
\text { of Soil }\end{array}$ & Profitability & $\begin{array}{l}\text { Ready } \\
\text { Market }\end{array}$ & $\begin{array}{l}\text { Regular } \\
\text { Income }\end{array}$ & $\begin{array}{l}\text { Income from by- } \\
\text { products }\end{array}$ \\
\hline $\begin{array}{l}\text { Marginal and Small } \\
\left(\mathbf{n}_{1}=26\right)\end{array}$ & 26 & 26 & 21 & 21 & 11 \\
\hline Semi-Medium $\left(n_{2}=25\right)$ & 25 & 25 & 24 & 25 & 0 \\
\hline Medium \&Large $\left(n_{3}=9\right)$ & 9 & 9 & 8 & 7 & 0 \\
\hline Total $(n=60)$ & $\begin{array}{c}60 \\
(100.00)\end{array}$ & $\begin{array}{c}60 \\
(100.00)\end{array}$ & $\begin{array}{c}53 \\
(88.33)\end{array}$ & $\begin{array}{c}53 \\
(88.33)\end{array}$ & $\begin{array}{c}11 \\
(18.33)\end{array}$ \\
\hline
\end{tabular}

Note: Figure in brackets shows per cent.

cost of production and enhancing profitability.

In conclusion, perish ability is one of the important constraints in banana production and marketing. Processing opportunities are absent to a great extent. The price of banana has been fluctuating violently and farmers are put to great loss and consumer is also not benefited. The review of status of banana production and marketing has revealed that there exist several gaps in the knowledge and information on all the above issues. Virtually banana is an integral component of socio-economic fabric of the people of state but it is now facing various constraints. Therefore there is need not only for enhancing the productivity but the quality is also required to be improved for increasing the profitability of real grower. So far no systematic studies have been conducted on economics of production and marketing of banana in Kosi Region of Bihar state.

\section{Policy implications}

From the findings of the study following conclusions can be drawn which give some implications regarding strategies to be framed to enhance the production, marketing and profitability of banana production in the study area:-

Banana being heavy feeder and labour intensive nature of crop, the growers should be trained on its nutrient and water management as well as on post-harvest management technology. This will help in

enhancing resource use efficiency, reducing
Banana, in study area is grown mainly under perennial monoculture system under assured irrigation. The usual economic life of plantation is 1-3 years, which means one planted crop and two ratoon crops. But the growers could hardly take $2^{\text {nd }}$ ratoon crop successfully due to one or other reason. The growers are required to be trained in management of ratoon crops for enhanced production/profitability. There is need of organizing growers to form Producer Company on the lines of Mahgrapes, Mahamango, Mahabanana etc. prevailing in Maharashtra state.

After repealing of APMC Act (since 2006) no alternate marketing method has been developed/implemented in the state. The farmers are forced to sell their produce through contractors/traders due to their inability in marketing activity. Direct marketing by producer to the consumers has been experimented through 'APNI MANDI' is the state of Punjab, Haryana and Uttarakhand. With certain modification it has also been implemented in Karnataka, Andhra Pradesh and Tamilnadu states. The same may be implemented in Bihar to safeguard the interest of farming community in general. Owing to annual production nature of banana, a large quantity of bio-waste is generated every year. Disposal of this waste material poses great problem to banana growers in the study area. This can be a source of fibre which has high value in market for its durability and strength. Therefore efforts should be made towards 
sustainable waste utilization by extraction of fibre and its conversion into various value added products like bags, wall hangings, pothangers, tablemats etc. to the possible extent.

Though the State Govt. has launched various programmes under Agriculture Road Map aimed to increase production, productivity and profitability of horticultural crops, their benefits are yet to be harvested by the farming community.

\section{References}

Ajjan, N. (1986) Regulated markets in Tamil Nadu: A Maladyremedy analysis. Agricultural Situation in India, 41(6): 455-458.

Arputhraj C. and Nair K. S. (1988). Economics of banana in Kerala. Agric.Situation in India, 43 (8): 707-708.

Ashtukar, B. W. and Deole C D (1985) Producer's Share in consumer's rupee A case study of fruit marketing in Maharashtra. Indian journal of Agricultural Economics 40(3): 403.

Biradar, K. S., and Kasar, D. V. (1984) A Study of relative efficiency of co-operatives vis-a- vis other Agencies in marketing of Jalgaon banana in Delhi market. Indian co-operative Review 22 (2): 231236.

Chavan, A.A., Kalyankar, S.P., S.V. and Wakle, P.K. (2001) A study of marketing of banana in Parbhani market of Maharashtra state. The Bihar Journal of Agricultural Marketing. IX (3):316-318.

Chennarayadu, K. C., Eswara, P. Y., Satyanarayana, G., and Sivaprasada, R. L. (1990) Land use efficiency of banana
-An application of frontier production Function. Agricultural Situation in India 45 (1): 15-17.

Deshmukh, D.D.S., and Bornare, P.P., and Anawade P.K. (2013) Constraints in Banana marketing and scope of improvement: A case study for Jalgaon region. PRATIBHA: International Journal of Science, Spirituality, Business and Technology 2(1).

Government of Bihar (2014-2015) Economic Survey, Finance Department, 66.

Maurya, O. P., Singh, G. N., and Kushwaha, R. K. S. (1996) Profitability of banana plantation in Hajipur district in Bihar. Bihar, Journal of Agricultural Marketing 4 (1): 68-70.

Mehta, R., and Srivastava, P. K.(2000) Analysis of seasonality in prices of Agricultural Commodities Agricultural Situation in India 57 (4): 311-314.

Ray, P.K. (2007) Banana Production and Research in Bihar: Present Status and Future trusts, Banana: Technology Advances, edited by Singh, H.P. and Uma, S, AIPUB, Trichy, pp 41-49.

Sarswat, S.P. (1999) An economic analysis of production and marketing of apple in Himachal Pradesh, The Bihar Journal of Agricultural Marketing, VII (3) pp 320328.

Singh, H.P., and Uma, S. (2007) Banana: Technological Advances, Association for the Improvement in Production and Utilization of Banana (AIPUB), NRC for Banana (ICAR), Trichy, India pp vii. Vigneshwara, V. (1988) Marketing of banana in India. Indian Journal of Marketing 18 (8-10): 29-30.

\section{How to cite this article:}

Priyanka Kumari, K.M. Singh and Santosh Kumar Atre. 2018. Problems and Constraints in Banana Cultivation: A Case Study in Bhagalpur District of Bihar. Int.J.Curr.Microbiol.App.Sci. 7(07): 1752-1759. doi: https://doi.org/10.20546/ijcmas.2018.707.208 